\title{
A Supramolecular Host-Guest Carrier System for Growth Factors Employing VHH Fragments
}

Citation for published version (APA):

Cabanas-Danes, J., Rodrigues, E. D., Landman, E., Van Weerd, J., van Blitterswijk, C., Verrips, T., Huskens, J., Karperien, M., \& Jonkheijm, P. (2014). A Supramolecular Host-Guest Carrier System for Growth Factors Employing VHH Fragments. Journal of the American Chemical Society, 136(36), 1267512681. https://doi.org/10.1021/ja505695w

Document status and date:

Published: 10/09/2014

DOI:

10.1021/ja505695w

Document Version:

Publisher's PDF, also known as Version of record

Document license:

Taverne

Please check the document version of this publication:

- A submitted manuscript is the version of the article upon submission and before peer-review. There can be important differences between the submitted version and the official published version of record.

People interested in the research are advised to contact the author for the final version of the publication, or visit the DOI to the publisher's website.

- The final author version and the galley proof are versions of the publication after peer review.

- The final published version features the final layout of the paper including the volume, issue and page numbers.

Link to publication

\footnotetext{
General rights rights.

- You may freely distribute the URL identifying the publication in the public portal. please follow below link for the End User Agreement:

www.umlib.nl/taverne-license

Take down policy

If you believe that this document breaches copyright please contact us at:

repository@maastrichtuniversity.nl

providing details and we will investigate your claim.
}

Copyright and moral rights for the publications made accessible in the public portal are retained by the authors and/or other copyright owners and it is a condition of accessing publications that users recognise and abide by the legal requirements associated with these

- Users may download and print one copy of any publication from the public portal for the purpose of private study or research.

- You may not further distribute the material or use it for any profit-making activity or commercial gain

If the publication is distributed under the terms of Article $25 \mathrm{fa}$ of the Dutch Copyright Act, indicated by the "Taverne" license above, 


\section{A Supramolecular Host-Guest Carrier System for Growth Factors Employing $\mathrm{V}_{\mathrm{H}} \mathrm{H}$ Fragments}

Jordi Cabanas-Danés, ${ }^{\dagger}$ Emilie Dooms Rodrigues, ${ }^{\ddagger}$ Ellie Landman, ${ }^{\ddagger}$ Jasper van Weerd, ${ }^{\dagger}, \dot{\dagger}$ Clemens van Blitterswijk, ${ }^{\S, \perp}$ Theo Verrips, ${ }^{\|}$Jurriaan Huskens, ${ }^{* \dagger}$ Marcel Karperien, ${ }^{*}, \dot{\ddagger}$ and Pascal Jonkheijm* ${ }^{\dagger}$

${ }^{\dagger}$ Molecular Nanofabrication Group, MESA ${ }^{+}$Institute for Nanotechnology, Faculty of Science and Technology, University of Twente, P.O. Box 217, 7500 AE Enschede, Netherlands

${ }^{\ddagger}$ Departments of Developmental Bioengineering and ${ }^{\S}$ Tissue Regeneration, MIRA Institute for Biomedical Technology and Technical Medicine, Faculty of Science and Technology, University of Twente, P.O. Box 217, 7500 AE, Enschede, Netherlands

"Cellular Architecture and Dynamics, Department of Biology, Faculty of Science, Utrecht University, Padualaan 8, 3584 CH Utrecht, Netherlands

${ }^{\perp}$ Department of Complex Tissue and Organ Regeneration, MERLN Institute, Maastricht University, Netherlands

Supporting Information

ABSTRACT: A supramolecular strategy is presented for the assembly of growth factors employing $\mathrm{His}_{6}$-tagged singledomain antibodies $\left(\mathrm{V}_{\mathrm{H}} \mathrm{H}\right)$. A combination of orthogonal supramolecular interactions of $\beta$-cyclodextrin $(\beta \mathrm{CD})$-adamantyl (Ad) host-guest and $N$-nitrilotriacetic acid (NTA)histidine (His) interactions was employed to generate reversible and homogeneous layers of growth factors. A single-domain antibody $\mathrm{V}_{\mathrm{H}} \mathrm{H}$ fragment was identified to bind to the human bone morphogenetic protein-6 (hBMP6) growth factor and could be recombinantly expressed in $E$. coli. The $\mathrm{V}_{\mathrm{H}} \mathrm{H}$ fragment was equipped with a $\mathrm{C}$-terminal hexahistidine $\left(\mathrm{His}_{6}\right)$ tether to facilitate the assembly on $\beta \mathrm{CD}$ surfaces using a linker that contains an Ad group to bind to the $\beta \mathrm{CD}$ receptors and an NTA moiety to interact with the $\mathrm{His}_{6}$-tag upon cocomplexation of $\mathrm{Ni}^{2+}$ ions. After exploring the thermodynamic and kinetic stability of the $\mathrm{V}_{\mathrm{H}} \mathrm{H}$ assemblies on $\beta \mathrm{CD}$ surfaces using a variety of experimental techniques including microcontact printing $(\mu \mathrm{CP})$, surface plasmon resonance (SPR), microscale thermophoresis (MST), and theoretical models for determining the thermodynamic behavior of the system, hBMP6 was assembled onto the $\mathrm{V}_{\mathrm{H}} \mathrm{H}$-functionalized surfaces. After analyzing the immobilized hBMP6 using immunostaining, the biological activity of hBMP6 was demonstrated in cell differentiation experiments. Early osteogenic differentiation was analyzed in terms of alkaline phosphatase (ALP) activity of KS483-4C3 mouse progenitor cells, and the results indicated that the reversibly immobilized growth factors were functionally delivered to the cells. In conclusion, the supramolecular strategy used here offers the necessary affinity, reversibility, and temporal control to promote biological function of the growth factors that were delivered by this strategy.

Gestos rowth factors are considered major therapeutic agents that profoundly affect cell function. ${ }^{1-6}$ However, direct bolus delivery or systemic administration of growth factors is of limited clinical use as excessive dosing is required to detect a measurable effect, which potentially could lead to off-target effects. ${ }^{7}$ Correct localization and balance of growth factors can be regulated by their encapsulation in carrier systems such as hydrogels, scaffolds or layer-by-layer systems, which generally sustain the spatial availability of growth factors facilitated by their diffusion into tissue. ${ }^{8-21}$ An elegant strategy recently reported by Maynard et al. relied on the stabilization of basic fibroblast growth factors by covalent conjugation with a heparin-mimicking polymer. ${ }^{22}$ Here we report the supramolecular capture of growth factors by using single monomeric variable antibody fragments engineered from heavy chain antibodies found in camelids $\left(\mathrm{V}_{\mathrm{H}} \mathrm{H}\right.$ fragments). Several therapeutic applications employing $\mathrm{V}_{\mathrm{H}} \mathrm{H}$ in cancer, infectious and immune diseases have recently been reviewed. ${ }^{23-25}$ Unique characteristics of $\mathrm{V}_{\mathrm{H}} \mathrm{H}$ fragments such as their small size (12$20 \mathrm{kDa}$ ), elevated stability in aqueous and even in organic solvents and higher temperatures and reproducible recombinant production make them promising candidates to explore for activating surfaces in tissue regeneration. In addition, selection of $\mathrm{V}_{\mathrm{H}} \mathrm{H}$ binders to growth factors can be conveniently done by means of phage display. $\mathrm{V}_{\mathrm{H}} \mathrm{Hs}$ are amenable for genetic engineering allowing the site-specific introduction of reactive groups, such as histidine tags, through which they can be sitespecifically immobilized to surfaces yielding homogeneously

Received: June 6, 2014

Published: August 25, 2014 
oriented layers of $\mathrm{V}_{\mathrm{H}} \mathrm{H}$ fragments under physiological conditions following supramolecular strategies. ${ }^{26,27}$

Supramolecular strategies, similar to bioresponsive covalent linkages such as ester or thiol linkages, yield reversibility providing a means to release growth factors and prompt a biological function directly influenced by the desorption. However, as opposed to such type of bioresponsive covalent linkages, supramolecular delivery can be controlled by valency and dissociation rate constants. Although supramolecular chemistry has been successfully used to create biomimetic systems, ${ }^{28-37}$ up to now, reports that show the potentialities of supramolecular growth factor delivery systems predominantly employ peptide fragments to allow for binding of growth factors to supramolecular assemblies. For example, Stupp et al. have bound transforming growth factor $\beta$-1 (TGF- $\beta$ ) to oligopeptides that were displayed on the surface of selfassembled nanotubular systems. ${ }^{38}$ Such supramolecular carrier systems promoted chondrogenic differentiation of human mesenchymal stem cells. ${ }^{38} \mathrm{Up}$ to now, promising reports exist on the use of supramolecular host-guest systems, such as cyclodextrin and cucurbituril hosts, for the delivery of transcription factors, ${ }^{39}$ for the release of peptides and proteins, $^{40-42}$ and to modulate cell adhesion; ${ }^{43-46}$ however, yet no reports exist for their application as growth factor carrier systems. $11,28-30,47$

We here present a supramolecular strategy to deliver growth factors on $\beta$-cyclodextrin $(\beta \mathrm{CD})$ surfaces using $\mathrm{V}_{\mathrm{H}} \mathrm{H}$ as an intermediate. The method requires simple assembly steps in physiological conditions and offers the possibility to fine-tune affinities and dissociation rate constants by molecular design. We demonstrate the feasibility of our approach using human bone morphogenetic protein 6 (hBMP-6) as a model growth factor that is not recombinantly available and therefore cannot be expressed with His-tags to allow for direct noncovalent immobilization. hBMP- 6 belongs to the TGF- $\beta$ superfamily and is known to play significant roles in cartilage and bone morphogenesis and repair and is already used as a therapeutic protein for inducing bone growth. ${ }^{48-50}$

\section{RESULTS AND DISCUSSION}

Design and Characterization of $\mathrm{V}_{\mathrm{H}} \mathrm{H}$ Construct. $\mathrm{V}_{\mathrm{H}} \mathrm{H}$ clones that bind to hBMP-6 were selected following a phage display approach (see the Supporting Information for details). Affinity selection (biopanning) was carried out on hBMP-6 coated plates $(0.2-5 \mu \mathrm{g} /$ well $)$, which were incubated with the phage $\mathrm{V}_{\mathrm{H}} \mathrm{H}$ immune library that was constructed after immunization of llamas. After the second round, the relative binding strength of selected phage $\mathrm{V}_{\mathrm{H}} \mathrm{H}$ clones was assessed against each other using an enzyme-linked immunosorbent assay (ELISA) (see Supporting Information Figure S1a). Subsequently, the strongest binding $\mathrm{V}_{\mathrm{H}} \mathrm{H}$ clone was subcloned in an expression vector with a C-terminal His-tag and recombinantly produced in E. coli hosts. After purification using affinity chromatography, a single band at $16 \mathrm{kDa}$ was detected by sodium dodecyl sulfate polyacrylamide gel electrophoresis (SDS-PAGE) (see Supporting Information Figure $\mathrm{S} 1 \mathrm{~b})$ in agreement with related $\mathrm{V}_{\mathrm{H}} \mathrm{H}$ binders described in literature. $2-25$

The interaction of the purified $\mathrm{V}_{\mathrm{H}} \mathrm{H}$ construct with hBMP-6 was confirmed using microscale thermophoresis (MST) and ELISA measurements. To determine the affinity between $\mathrm{V}_{\mathrm{H}} \mathrm{H}$ and hBMP- 6 in solution, MST was used. A titration series of hBMP- 6 over a range of $0.04 \mathrm{nM}$ to $0.7 \mu \mathrm{M}$ was performed while fluorescently labeled $\mathrm{V}_{\mathrm{H}} \mathrm{H}$ was kept constant at $20 \mathrm{nM}$ throughout the series. Upon binding of hBMP-6, a change in thermophoretic signal was observed as shown in Figure 1a.
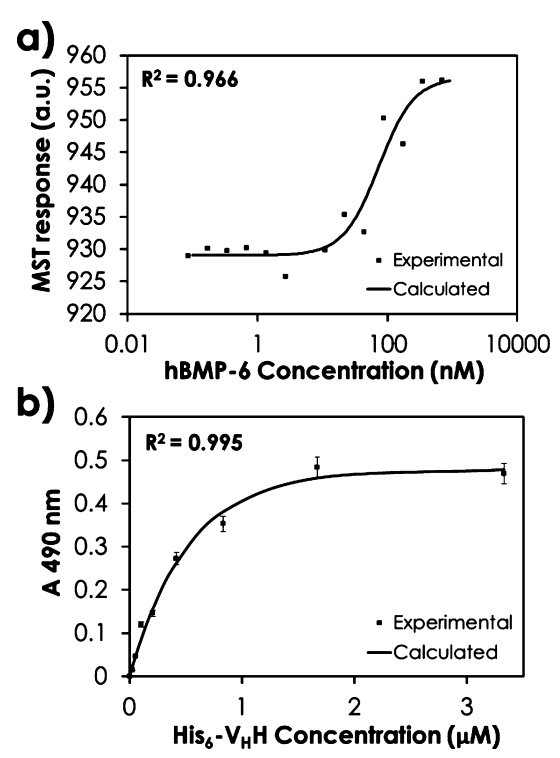

Figure 1. $\mathrm{V}_{\mathrm{H}} \mathrm{H}$ binding to hBMP-6 analyzed (a) in solution by microscale thermophoresis (MST) and (b) on microtiter plates by ELISA (duplicate read-out).

Subsequent fitting of the data to a 1:1 binding model yielded a dissociation constant $K_{\mathrm{d}}$ of $7.4( \pm 0.4) \times 10^{-8} \mathrm{M}$ and therefore $K_{\mathrm{a}}=1 / K_{\mathrm{d}}=1.4 \times 10^{7} \mathrm{M}^{-1}$. These values are comparable to the ones found in literature for $\mathrm{V}_{\mathrm{H}} \mathrm{H}$ interactions with different binding partners. ${ }^{22-25,51-53}$ The obtained affinity was compared with affinity studies carried out in an ELISA assay format. To the hBMP- 6 coated microtiter plates, a series of $\mathrm{V}_{\mathrm{H}} \mathrm{H}$ solutions in the range of $0-3.3 \mu \mathrm{M}$ was added and assayed by ELISA (Figure 1b). After fitting the experimental data to a Langmuir model, a $K_{\mathrm{a}}$ of $1.9( \pm 0.2) \times 10^{6} \mathrm{M}^{-1}$ was estimated, which is 1 order of magnitude lower than the affinity measured by MST, which is a known effect when comparing solution assays with array formats. ${ }^{26,27}$

Surface Assembly Analysis. With these $\mathrm{V}_{\mathrm{H}} \mathrm{H}$ constructs with high affinity toward hBMP-6 in hand, we sought to employ the C-terminal $\mathrm{His}_{6}$-tag on the recombinantly produced $\mathrm{V}_{\mathrm{H}} \mathrm{H}$ for the assembly onto supramolecular $\beta \mathrm{CD}$ host surfaces through specific interaction with adamantyl (Ad) guest functionalized nitrilotriacetic acid (NTA) linkers. ${ }^{54-58}$ To fabricate this supramolecular carrier system, a stepwise assembly process (Scheme 1) was adopted using the (NTA)-Ni(II)- His $_{6}$-tag interaction and orthogonal linkers consisting of three steps, that is, (1) preincubation of the $\beta \mathrm{CD}$ surface with an ethylene glycol based monoadamantyl linker (HEG-Ad) for minimizing the nonspecific protein adsorption, (2) a solution of NTA-monoadamantyl linker (NTA-Ad) and $\mathrm{V}_{\mathrm{H}} \mathrm{H}$ in the presence of $\mathrm{Ni}(\mathrm{II})$ ions while maintaining the same concentration of HEG-Ad, and (3) a solution of hBMP-6 was used. $^{39,40}$ Alternatively, after assembling HEG-Ad, a one-pot assembly step with all components was performed (Scheme 1). The assembly was performed at a physiological $\mathrm{pH}$ of 7.4, which ensures complexation of $\mathrm{Ni}(\mathrm{II})$ ions to the majority of the NTA moieties. ${ }^{50}$

Supramolecular $\beta$ CD host monolayers on gold were placed in an SPR flow cell. ${ }^{40}$ After the baseline became stable while 
Scheme 1. Schematic Presentation of the Assembly of hBMP-6 on Supramolecular $\beta$ CD Host Surfaces ${ }^{a}$
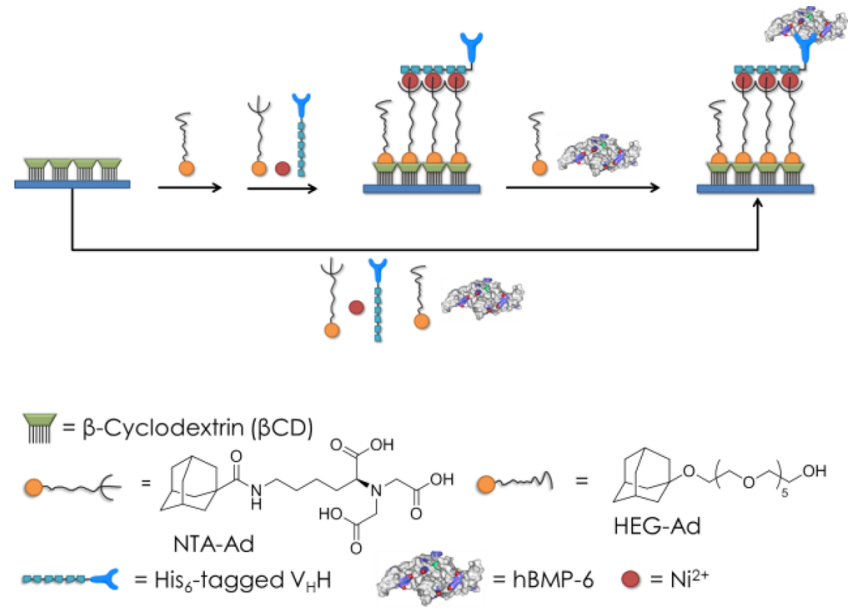

${ }^{a}$ The self-assembly follows either a stepwise (three steps) or one-pot procedure. See text for details. Chemical structures of the building blocks are given at the bottom.

flowing PBS buffer, a solution of HEG-Ad (0.1 mM in PBS) was flown for $10 \mathrm{~min}$ until a stable signal was observed (Figure 2a, triangles). Successively, a solution of $0.5 \mu \mathrm{M} \mathrm{V} \mathrm{V}_{\mathrm{H}} \mathrm{H} \cdot \mathrm{Ni}(\mathrm{II})$. NTA-Ad (in a ratio of 1:5:5) in the presence of $0.1 \mathrm{mM}$ HEGAd was injected and flown continuously $\left(0.1 \mathrm{~mL} \mathrm{~min}^{-1}\right)$ (Figure 2a, squares). The observed increase in the SPR signal reached thermodynamic equilibrium after $10 \mathrm{~min}$ (Figure 2a,

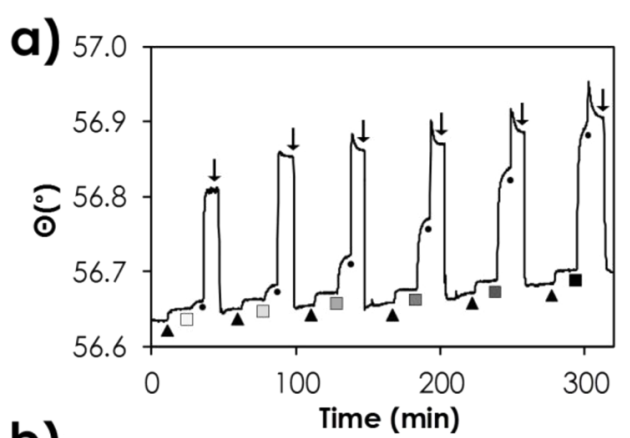

b)

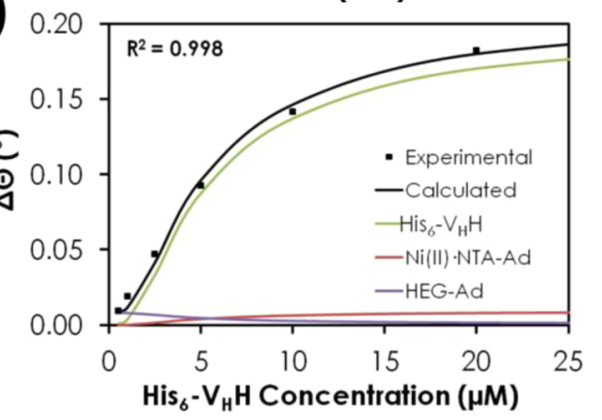

Figure 2. (a) SPR data of a titration series of $\mathrm{V}_{\mathrm{H}} \mathrm{H} \cdot \mathrm{Ni}(\mathrm{II}) \cdot \mathrm{NTA}-\mathrm{Ad}$ (1:5:5) to $\beta$ CD plates in the presence of $0.1 \mathrm{mM}$ HEG-Ad. Symbols indicate switching of the buffer to $0.1 \mathrm{mM}$ HEG-Ad $(\boldsymbol{\Delta})$, increasing concentrations of $\mathrm{V}_{\mathrm{H}} \mathrm{H} \cdot \mathrm{Ni}(\mathrm{II}) \cdot \mathrm{NTA}-\mathrm{Ad}(1: 5: 5 ; \square \rightarrow \boldsymbol{\square})$ in the presence of $0.1 \mathrm{mM}$ HEG-Ad, $10 \mathrm{mM} \beta \mathrm{CD} / \mathrm{EDTA}$ in PBS $(\bullet)$ and PBS $(\downarrow)$. (b) Experimental change of SPR resonant angle $(\Delta \Theta$ at thermodynamic equilibrium; black markers) versus $\mathrm{V}_{\mathrm{H}} \mathrm{H}$ concentration fitted to the theoretical model (see Supporting Information). The contribution of the assembly of the different molecules to the signal is given. spheres)). This observation indicates that $\mathrm{V}_{\mathrm{H}} \mathrm{H} \cdot(\mathrm{Ni}(\mathrm{II}) \cdot \mathrm{NTA}$ Ad $)_{x}(x=1-3)$ species have replaced monovalent HEG-Ad, confirming that higher valent adamantyl $\mathrm{V}_{\mathrm{H}} \mathrm{H} \cdot(\mathrm{Ni}(\mathrm{II}) \cdot \mathrm{NTA}$ Ad $)_{x}(x>1)$ were preferentially interacting with the supramolecular $\beta \mathrm{CD}$ host surface as determined by the effective concentration $\left(C_{\text {eff }}\right)$ (vide infra). To demonstrate the reversibility of the assembly of $\mathrm{V}_{\mathrm{H}} \mathrm{H}$, a solution containing 10 $\mathrm{mM}$ of competing ligand EDTA and $10 \mathrm{mM}$ of $\beta \mathrm{CD}$ in PBS were added to the flow cell while monitoring the SPR response (Figure 2a, circles). Although a sudden initial increase in the SPR intensity was observed due to the large change in refractive index when using a concentrated solution of EDTA and $\beta C D$, the baseline was totally restored upon rinsing the system with PBS for $5 \mathrm{~min}$ (Figure 2a, arrows). This result indicates the complete disassembly of the molecules from the $\beta \mathrm{CD}$ surface. To assess the thermodynamic stability of the $\mathrm{V}_{\mathrm{H}} \mathrm{H}$ constructs at the $\beta \mathrm{CD}$ surface, a titration series of $\mathrm{V}_{\mathrm{H}} \mathrm{H} \cdot \mathrm{Ni}(\mathrm{II}) \cdot \mathrm{NTA}-\mathrm{Ad}$ (1:5:5) in the range of $0.5-20 \mu \mathrm{M}$ was performed while recording the change in the SPR resonant angle. Between each titration step, a disassembly cycle was performed to restore the $\beta \mathrm{CD}$ surface as described above. Upon addition of HEG-Ad, which represents the first step of the assembly of each titration step, a constant increase in SPR intensity was observed (Figure $2 a)$. The second step of the assembly was marked by a gradual increase in the change of the SPR resonant angle saturating above $20 \mu \mathrm{M}$ of $\mathrm{V}_{\mathrm{H}} \mathrm{H}$ (Figure 2).

The SPR data were satisfactorily fitted to a thermodynamic model that accounts for all species possibly bound to the $\beta \mathrm{CD}$ surface (Figure $2 \mathrm{~b}$; see the Supporting Information for details). The model shows that, at low concentrations of $\mathrm{V}_{\mathrm{H}} \mathrm{H}(<1 \mu \mathrm{M})$, the major contribution to the (still low) SPR signal originates from the assembly of monovalent HEG-Ad, while above $2 \mu \mathrm{M}$ $\mathrm{V}_{\mathrm{H}} \mathrm{H}$, when the coverage becomes appreciable, the major contribution to the rise in SPR signal originates from trivalent $\mathrm{V}_{\mathrm{H}} \mathrm{H} \cdot(\mathrm{Ni}(\mathrm{II}) \cdot \mathrm{NTA}-\mathrm{Ad})_{3}$ species $(70 \%)$ as expected. ${ }^{55}$ This indicates that the trivalent complex is the main species contributing to the coverage at the whole range of concentrations until surface saturation (see Figure $2 \mathrm{~b}$ and Supporting Information Figure S2). Fixing the values of the intrinsic binding constants $K_{i, \mathrm{HEG}}=2.6 \times 10^{4} \mathrm{M}^{-1}$ and $K_{i, \mathrm{NTA}}=$ $1.2 \times 10^{4} \mathrm{M}^{-1}$ as found in literature, ${ }^{51}$ an association constant $K_{1}$ of $6.3 \times 10^{4} \mathrm{M}^{-1}$, which represents the first interaction of $\mathrm{Ni}$ (II)-NTA-Ad to the $\mathrm{His}_{6}$-tag, and a value for $C_{\text {eff }}$ of $0.02 \mathrm{M}$ were found to fit the experimentally observed changes in SPR resonant angle (Figure $2 \mathrm{~b}$ ). From these values, the second $\left(K_{2}\right)$ and third $\left(K_{3}\right)$ association constants of the consecutive bonding of $\mathrm{His}_{2}$-units to $\mathrm{Ni}(\mathrm{II}) \cdot \mathrm{NTA}$-Ad were calculated to be $1.5 \times 10^{4}$ and $1.95 \times 10^{3} \mathrm{M}^{-1}$, respectively, in agreement with values found in literature. ${ }^{50,57}$ The overall binding constant for the trivalent complex on the $\beta \mathrm{CD}$ surface $\left(\left[\mathrm{V}_{\mathrm{H}} \mathrm{H}\right]=2 \mu \mathrm{M}\right.$ and $[\mathrm{Ni}(\mathrm{II}) \cdot \mathrm{NTA}-\mathrm{Ad}]=10 \mu \mathrm{M})$ was calculated to be in the order of $10^{6} \mathrm{M}^{-1}$, in agreement with literature, ${ }^{58}$ and for the divalent complex in the order of $10^{5} \mathrm{M}^{-1}$. In both cases, the multivalent interactions lead to highly stable assemblies bound to the surface while still being reversible.

Release of $\mathrm{V}_{\mathrm{H}} \mathrm{H}$ Fragments. To visualize the release of the $\mathrm{V}_{\mathrm{H}} \mathrm{H}$ carrier system, fluorescence microscopy was used. To this end, $\mathrm{V}_{\mathrm{H}} \mathrm{H}$ was first fluorescently labeled with a Cy3-dye following standard procedures (see the Supporting Information). Cy3- $\mathrm{V}_{\mathrm{H}} \mathrm{H}$ was used for patterning employing the wellestablished microcontact printing $(\mu \mathrm{CP})$ method with a polydimethylsiloxane (PDMS) stamp. ${ }^{40,59}$ Such stamps were inked for $2 \mathrm{~min}$ with a mixture of $1 \mu \mathrm{M}$ Cy3 $-\mathrm{V}_{\mathrm{H}} \mathrm{H} / \mathrm{Ni}(\mathrm{II}) /$ 
NTA-Ad (1:5:5) in PBS buffer. After inking, the stamp was blown dry and put into conformal contact with a supramolecular host glass surface for $5 \mathrm{~min}$. After removing the stamp, the slides were directly imaged. As a reference, the same experiment was performed in which the PDMS stamp was inked with a $1 \mu \mathrm{M}$ solution of $\mathrm{V}_{\mathrm{H}} \mathrm{H}$ without $\mathrm{Ni}$ (II)/NTA-Ad added. In both cases, uniform dot patterns of $50 \mu \mathrm{m}$ diameter and spaced by $10 \mu \mathrm{m}$ were clearly visible with an excellent contrast with the background as imaged using fluorescence microscopy (see Figure 3a and Supporting Information Figure
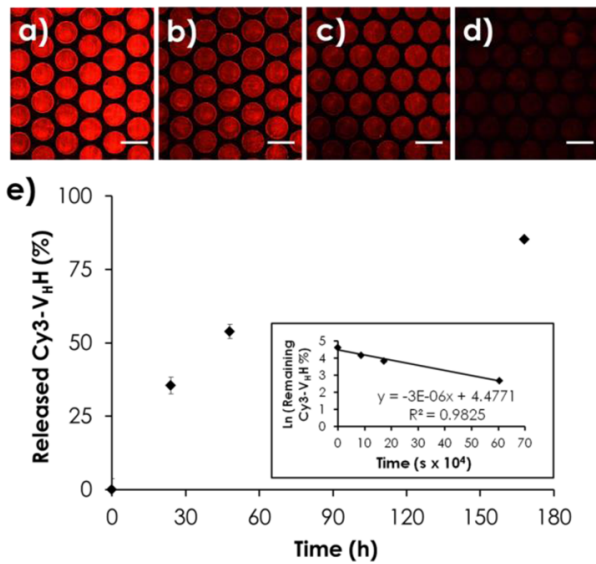

Figure 3. (a) Fluorescence microscopy image of $\mathrm{Cy} 3-\mathrm{V}_{\mathrm{H}} \mathrm{H}$ patterned by $\mu \mathrm{CP}$ on $\beta \mathrm{CD}$ glass slides recorded immediately after printing and washing. Frames recorded with $0.2 \mathrm{~s}$ exposure time after immersion for (b) $24 \mathrm{~h},(\mathrm{c}) 48 \mathrm{~h}$, and (d) $168 \mathrm{~h}$ in cell culture medium. Scale bars indicate $100 \mu \mathrm{m}$. (e) Release of $\mathrm{Cy} 3-\mathrm{V}_{\mathrm{H}} \mathrm{H}$ is plotted relative to the initial fluorescence intensity versus time. Inset shows the linear fitting of the corresponding logarithmic values.

S3). After extensive rinsing for $30 \mathrm{~min}$ with PBS, the patterns disappeared in the case of the reference experiment, which lacked the supramolecular NTA-Ad linker, whereas clear patterns remained visible in the case when NTA-Ad was coprinted (see Supporting Information Figure S3). These results indicate that the interactions between $\mathrm{V}_{\mathrm{H}} \mathrm{H}$ and the surface are governed by specific NTA $\cdot \mathrm{Ni}(\mathrm{II}) \cdot \mathrm{His}_{6}$-tag interactions as envisioned. Subsequently, after washing the patterns of the supramolecular $\mathrm{V}_{\mathrm{H}} \mathrm{H}$ carrier system with a solution containing $10 \mathrm{mM}$ of $\beta \mathrm{CD}$ and EDTA, the patterns disappeared (see Supporting Information Figure S3), which is characteristic of reversible supramolecular interactions between the protein and the surface. The observations made by fluorescence microscopy suggest that homogeneous layers of oriented $\mathrm{V}_{\mathrm{H}} \mathrm{H}$ are fabricated as a result of specific and reversible supramolecular interactions, in agreement with the SPR studies.

To acquire more information about the release of the $\mathrm{V}_{\mathrm{H}} \mathrm{H}$ fragments from the supramolecular $\mathrm{V}_{\mathrm{H}} \mathrm{H}$ carrier system under in vitro conditions, a series of substrates patterned with $\mathrm{Cy3}$ $\mathrm{V}_{\mathrm{H}} \mathrm{H} \cdot \mathrm{Ni}(\mathrm{II}) \cdot \mathrm{NTA}$-Ad were immersed in cell culture medium and four frames were recorded with a $0.2 \mathrm{~s}$ exposure time using an inverted fluorescence microscope (Figure $3 a-d)$. When plotting the decay of the fluorescence intensity versus time (Figure 3e), after 7 days around $80 \%$ of the fluorescence of the Cy3 $-\mathrm{V}_{\mathrm{H}} \mathrm{H}$ disappeared from the $\beta \mathrm{CD}$ host surfaces. When the data were fitted with first-order kinetics, a dissociation rate constant of $k_{\mathrm{d}}=\sim 10^{-6} \mathrm{~s}^{-1}$ was found, which compares favorably to an example in literature of immobilizing $\mathrm{His}_{6}$ tagged proteins on covalently modified NTA surfaces. ${ }^{60}$
Growth Factor Assembly. The ability to extend the release of $\mathrm{V}_{\mathrm{H}} \mathrm{H}$ beyond days provides an interesting opportunity to apply our supramolecular carrier system for the delivery of growth factors to cells. To investigate whether the $\mathrm{V}_{\mathrm{H}} \mathrm{H}$ carrier system can be loaded with hBMP- 6 growth factors, patterns of dots of $\mathrm{V}_{\mathrm{H}} \mathrm{H}$ were fabricated on glass slides as described above and subsequently incubated with a solution containing hBMP-6 $(0.7 \mu \mathrm{M})$ for $1 \mathrm{~h}$, according to the stepwise approach (Scheme 1). After sequential coupling for $1 \mathrm{~h}$ of a primary antibody (Ab) specific to hBMP-6 and a FITC-labeled secondary $\mathrm{Ab}$, the slides were imaged using fluorescence microscopy. The recorded images show clearly that the fluorescently labeled antibody was selectively immobilized on the printed $\mathrm{V}_{\mathrm{H}} \mathrm{H}$ patterns (Figure $4 \mathrm{a}$ ). When surfaces were
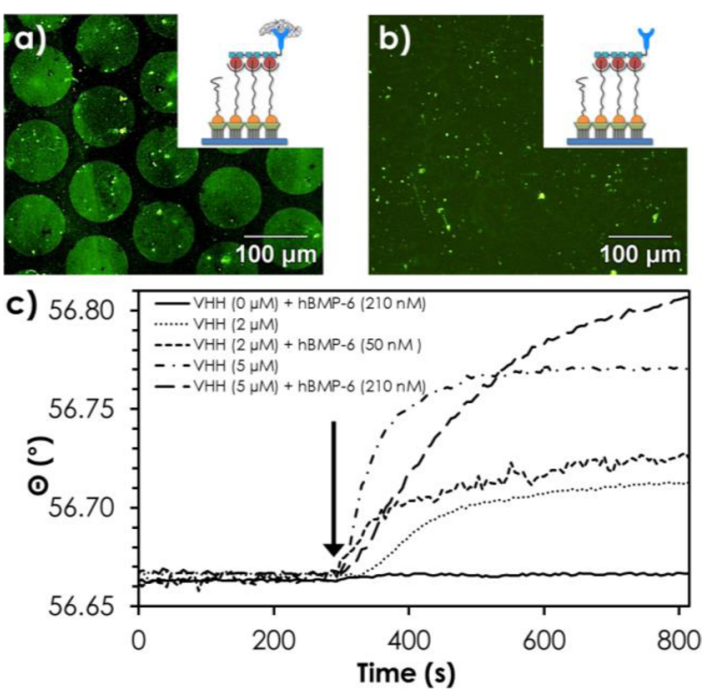

Figure 4. Fluorescence microscopy images after immunostaining the patterned (dots of $100 \mu \mathrm{m}$ in diameter and spaced by $20 \mu \mathrm{m}$ ) supramolecular $\mathrm{V}_{\mathrm{H}} \mathrm{H}$ carrier systems (a) loaded and (b) unloaded with hBMP-6. Insets show a scheme representing each assembly. (c) SPR sensograms of flowing $\mathrm{V}_{\mathrm{H}} \mathrm{H} \cdot \mathrm{Ni}$ (II).NTA-Ad with/without hBMP-6 as indicated in the legend over a $\beta \mathrm{CD}$ slide. The solutions were premixed for at least $30 \mathrm{~min}$ before injection (arrow) in the presence of $0.1 \mathrm{mM}$ of HEG-Ad.

blocked with BSA in addition to HEG-Ad prior to incubating the slides with hBMP-6 and antibodies, the signal-to-noise was enhanced. When the immunoassay was carried out on the $\mathrm{V}_{\mathrm{H}} \mathrm{H}$ patterns in the absence of hBMP-6, no fluorescent patterns were observed (Figure $4 \mathrm{~b}$ ). Similar results were obtained when the one-pot procedure was followed. When hBMP-6 loaded surfaces were immersed in cell culture medium, inspection of the surfaces using fluorescence microscopy showed that the disappearance of the growth factor and $\mathrm{V}_{\mathrm{H}} \mathrm{H}$ fragments occurred in the same time window as compared to the $\mathrm{V}_{\mathrm{H}} \mathrm{H}$ only system. Presumably, the dissociation of our carrier system relates to initial disruption of $\mathrm{Ad} / \beta \mathrm{CD}$ interactions $\left(k_{\mathrm{d}}=4 \times\right.$ $\left.10^{-3} \mathrm{~s}^{-1}\right)^{61}$ and, once in solution, the multivalency of the $\mathrm{V}_{\mathrm{H}} \mathrm{H}$. $\mathrm{Ni}(\mathrm{II}) \cdot(\mathrm{NTA}-\mathrm{Ad})_{3}$ will be lost, followed by the eventual dissociation of the growth factor from the $\mathrm{V}_{\mathrm{H}} \mathrm{H}$ fragments. SPR studies were also performed in the case of following the onepot assembly scheme. After recording a baseline by continuously flowing a solution of $0.1 \mathrm{mM}$ HEG-Ad, the flow was switched to a solution of hBMP-6 in the presence of different concentrations of $\mathrm{V}_{\mathrm{H}} \mathrm{H}$ (and $\mathrm{Ni}(\mathrm{II}) \cdot \mathrm{NTA}-\mathrm{Ad}$ ) while monitoring the SPR intensity (Figure 4c). When a $50 \mathrm{nM}$ 
solution of hBMP-6 was used in the presence of a $2 \mu \mathrm{M}$ solution of $\mathrm{V}_{\mathrm{H}} \mathrm{H}$, an increase in the SPR resonant angle was observed when compared to the case when a $2 \mu \mathrm{M}$ solution of $\mathrm{V}_{\mathrm{H}} \mathrm{H} \cdot \mathrm{Ni}(\mathrm{II}) \cdot \mathrm{NTA}-\mathrm{Ad}$ was flown without hBMP-6 (Figure 4c, short dashed versus dotted line). A similar observation was made when using a $210 \mathrm{nM}$ solution of hBMP-6 in the presence of a $5 \mu \mathrm{M}$ solution of $\mathrm{V}_{\mathrm{H}} \mathrm{H}$ (Figure $4 \mathrm{c}$, long-dashed versus dot-dashed line). When a solution containing only hBMP-6 was flown, no increase in the SPR intensity was observed, indicating that nonspecific interactions between hBMP-6 and the background surface are insignificant (Figure, $4 c$, straight line). These results confirm that hBMP-6 can specifically be loaded onto the $\mathrm{V}_{\mathrm{H}} \mathrm{H}$ carrier system, in agreement with MST and ELISA studies, while in addition hBMP-6 can be immuno-stained on the $\mathrm{V}_{\mathrm{H}} \mathrm{H}$ carrier system, presumably indicating that the active conformation of the growth factor is maintained.

Cell Response. To explore the bioactivity of the supramolecularly loaded hBMP-6 surfaces, the induction of alkaline phosphatase (ALP) was measured as early marker of osteogenic differentiation of KS483 mouse progenitor cells. ${ }^{62,63}$ Cell line KS483 is a mesenchymal precursor cell line that differentiates into osteoblasts during a 1-3 week culture period when cultured under osteogenesis-inducing conditions. ${ }^{62,63}$ While mature human and mouse BMP-6 share 96\% amino acid identity and their cross reactivity with mouse and human BMP receptors, the use of a murine cell line, such as KS483, is suitable to assess the ability of hBMP-6 to initiate differentiation into mineralizing osteoblasts. ${ }^{62,63}$ After cell culturing on fully coated (nonpatterned) hBMP-6 surfaces for 7 days, a live/dead assay showed negligible cytotoxicity (Figure 5c). From a series of fully coated hBMP- 6 surfaces and controls, the ALP activity was measured and normalized to the DNA content. Data is expressed as relative induction in comparison to a bare glass substrates (Figure 5a) or to a layer of immobilized $\mathrm{V}_{\mathrm{H}} \mathrm{H}$ (Figure $5 \mathrm{~b}$ ). When hBMP-6 was loaded onto the $\mathrm{V}_{\mathrm{H}} \mathrm{H}$ carrier system in a step-by-step assembly process, the ALP activity was 6-fold higher in comparison to the case when $\mathrm{V}_{\mathrm{H}} \mathrm{H}$ functionalized surfaces were used that lacked hBMP-6 (Figure 5a). In contrast, ALP activity was enhanced at best 2fold when soluble hBMP-6 was simply adsorbed to surfaces that lack the $\mathrm{V}_{\mathrm{H}} \mathrm{H}$ carrier system or glass only. No induction of ALP activity was observed for the $\mathrm{V}_{\mathrm{H}} \mathrm{H}$ carrier system without hBMP-6. These results confirm that presenting hBMP-6 through $\mathrm{V}_{\mathrm{H}} \mathrm{H}$ functionalized surfaces show the best differentiation response as assessed by measuring ALP activity after 7 days of differentiation. ${ }^{61-63}$ This increase in differentiation response could be attributed to the activity of hBMP- 6 only. When hBMP-6 was partly denatured at $95{ }^{\circ} \mathrm{C}$ after loading the $\mathrm{V}_{\mathrm{H}} \mathrm{H}$ carrier system, the ALP activity was significantly decreased. An ELISA experiment was performed to determine the amount of surface loaded hBMP- 6 on the $\mathrm{V}_{\mathrm{H}} \mathrm{H}$ carrier system, which was prepared following the step-by-step procedure. The released amount of hBMP-6 after 7 days was determined to be $142 \pm 17 \mathrm{ng}$. This result may give reason to the higher ALP activity observed for hBMP- 6 loaded surfaces when compared with reference experiments on glass and on substrates functionalized with $\mathrm{V}_{\mathrm{H}} \mathrm{H}$ in which $100 \mathrm{ng}$ of hBMP-6 was added to the cell culture medium. However, when cells were seeded on hBMP- 6 loaded surfaces that were prepared following the one-pot assembly procedure using a solution of $100 \mathrm{ng}$ of hBMP-6 and $0.5 \mu \mathrm{M} \mathrm{V} \mathrm{V}_{\mathrm{H}} \mathrm{H} \cdot \mathrm{Ni}(\mathrm{II}) \cdot \mathrm{NTA}-\mathrm{Ad}(1: 5: 5)$, a 6 -fold relative induction of the ALP production was observed
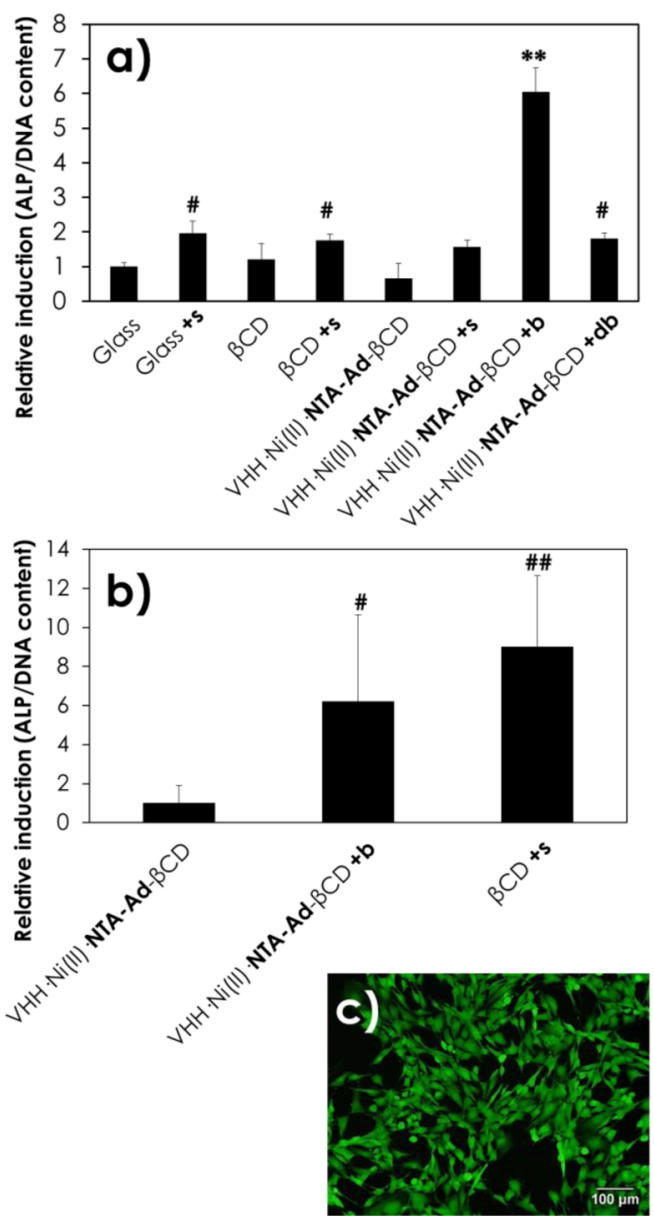

Figure 5. ALP activity normalized by the total DNA content of KS483 cells after 7 days of culture, expressed as relative induction with respect to (a) a glass control following a step-by-step assembly procedure or to (b) a supramolecular $\mathrm{V}_{\mathrm{H}} \mathrm{H}$ carrier system following a one-pot assembly procedure. Notation on $x$-axis: "s" represents represents soluble hBMP-6 supplemented to the cell medium; "b" represents hBMP-6 bound to the carrier system (fully coated) ; "db" represents hBMP-6 denatured at high temperature upon loading the carrier system (fully coated). ${ }_{p} p<0.05$ compared to $\mathrm{V}_{\mathrm{H}} \mathrm{H} \cdot \mathrm{Ni}(\mathrm{II}) \cdot \mathrm{NTA}-\mathrm{Ad},{ }^{\#} p<0.01$ compared to $\mathrm{V}_{\mathrm{H}} \mathrm{H} \cdot \mathrm{Ni}(\mathrm{II}) \cdot \mathrm{NTA}-\mathrm{Ad}$, and $* * p<0.01$ compared to all cases. (c) Live-dead assay showing KS483 cells seeded on supramolecular $\mathrm{V}_{\mathrm{H}} \mathrm{H}$ carrier system loaded with hBMP-6 (fully coated).

with respect to the case when hBMP-6 was left out of the assembly solution to give $\mathrm{V}_{\mathrm{H}} \mathrm{H}$-only surfaces (Figure $5 \mathrm{~b}$ ). These results show that irrespective of the assembly procedure, biologically relevant amounts of hBMP-6 can be functionally delivered to cells through the supramolecular $\mathrm{V}_{\mathrm{H}} \mathrm{H}$ carrier system.

\section{CONCLUSION}

We demonstrated that employing $\mathrm{V}_{\mathrm{H}} \mathrm{H}$ fragments gives access to capturing growth factors with high affinities while their recombinant production is convenient and gives entry to modification through genetic engineering. While $\mathrm{V}_{\mathrm{H}} \mathrm{H}$ fragments resemble human antibodies, immune response is presumably negligible as opposed to other peptide systems. ${ }^{23-25}$ Our results show that, irrespective of the assembly procedure, biologically relevant amounts of hBMP-6 can be functionally loaded onto the supramolecular $\mathrm{V}_{\mathrm{H}} \mathrm{H}$ carrier 
system and successively delivered to cells. We show that growth factors can be sequestered to the $\mathrm{V}_{\mathrm{H}} \mathrm{H}$ carrier system, indicating that locally excreted growth factors can possibly be bound to the surface assisted by $\mathrm{V}_{\mathrm{H}} \mathrm{H}$. Introduction of supramolecular coupling strategies offers additional opportunities to modulate release profiles through variation of binding strengths ${ }^{40}$ and dissociation rates or combination of supramolecular with covalent strategies. ${ }^{65}$ Using oriented $\mathrm{V}_{\mathrm{H}} \mathrm{H}$ fragments on surfaces to carry growth factors provides a novel opportunity to incorporate growth factors in various systems such as hydrogels or scaffolds, ${ }^{45}$ and we believe that this will open new ways to develop instructed biomaterials.

\section{ASSOCIATED CONTENT}

\section{S Supporting Information}

Experimental details. This material is available free of charge via the Internet at http://pubs.acs.org."

\section{AUTHOR INFORMATION}

\section{Corresponding Authors}

j.huskens@utwente.nl

h.b.c.karperien@utwente.nl

p.jonkheijm@utwente.nl

\section{Notes}

The authors declare no competing financial interest.

\section{ACKNOWLEDGMENTS}

Work by J.C.-D., E.D.R., and E.L. was funded by Project P2.02 OAcontrol of the research program of the BioMedical Materials Institute, cofunded by the Dutch Ministry of Economic Affairs. Work by J.v.W. was funded by Nanonext NL (06C.11). The work by P.J. was funded by a starting grant from the European Research Council (no. 259183 Sumoman).

\section{REFERENCES}

(1) Boden, S. D.; Kang, J.; Sandhu, H.; Heller, J. G. Spine 2002, 27, 2662.

(2) Takeshita, S.; Zheng, L. P.; Brogi, E.; Kearney, M.; Pu, L. Q.; Bunting, S.; Ferrara, N.; Symes, J. F.; Isner, J. M. J. Clin. Invest. 1994, 93, 662 .

(3) Takeshita, S.; Pu, L. Q.; Stein, L. A.; Sniderman, A. D.; Bunting, S.; Ferrara, N.; Isner, J. M.; Jeffrey, M.; Symes, J. F. Circulation 1994, 90, 228.

(4) Baumgartner, I.; Pieczek, A.; Manor, O.; Blair, R.; Kearney, M.; Walsh, K.; Isner, J. M. Circulation 1998, 97, 1114.

(5) Hendel, R. C.; Henry, T. D.; Rocha-Singh, K.; Isner, J. M.; Kereiakes, D. J.; Giordano, F. J.; Simons, M.; Bonow, R. O. Circulation 2000, 101, 118.

(6) Lee, C. H.; Cook, J. L.; Mendelson, A.; Moioli, E. K.; Yao, H.; Mao, J. J. Lancet 2010, 376, 440.

(7) Yancopoulos, G. D.; Davis, S.; Gale, N. W.; Rudge, J. S.; Wiegand, S. J.; Holash, J. Nature 2000, 407, 242.

(8) Boontheekul, T.; Mooney, D. J. Curr. Opin. Biotechnol. 2003, 14, 559.

(9) Patterson, J.; Martino, M. M.; Hubbell, J. A. Mater. Today 2010, 13, 14.

(10) Boudou, T.; Crouzier, T.; Ren, K.; Blin, G.; Picart, C. Adv. Mater. 2010, 22, 441.

(11) Cabanas-Danés, J.; Huskens, J.; Jonkheijm, P. J. Mater. Chem. B 2014, 2, 2381.

(12) Murray, J.; Brown, L.; Langer, R. Cancer Drug Delivery 1984, 1, 119.

(13) Edelman, E. R.; Mathiowitz, E.; Langer, R.; Klagsbrun, M. Biomaterials 1991, 12, 619.

(14) Gombotz, W. R.; Pettit, D. K. Bioconjugate Chem. 1995, 6, 332.
(15) Mahoney, M. J.; Saltzman, W. M. Proc. Natl. Acad. Sci. U.S.A. 1999, 96, 4536

(16) Lee, K. Y.; Peters, M. C.; Anderson, K. W.; Mooney, D. J. Nature 2000, 408, 998.

(17) Richardson, T. P.; Peters, M. C.; Ennett, A. B.; Mooney, D. J. Nat. Biotechnol. 2001, 19, 1029.

(18) Crouzier, T.; Fourel, L.; Boudou, T.; Albigès-Rizo, C.; Picart, C. Adv. Mater. 2011, 23, H111.

(19) Crouzier, T.; Ren, K.; Nicolas, K.; Roy, C.; Picart, C. Small 2009, 5, 598.

(20) Bastings, M. M. C.; Koudstaal, S.; Kieltyka, R. E.; Nakano, Y.; Pape, A. C. H.; Feyen, D. A. M.; van Slochteren, F. J.; Doevendans, P. A.; Sluijter, J. P. G.; Meijer, E. W.; Chamuleau, S. A. J.; Dankers, P. Y. W. Adv. Healthcare Mater. 2013, 3, 70.

(21) Wylie, R. G.; Ahsan, S.; Aizawa, Y.; Maxwell, K. L.; Morshead, C. M.; Shoichet, M. S. Nat. Mater. 2011, 10, 799.

(22) Nguyen, T. H.; Kim, S.-H.; Decker, C. G.; Wong, D. Y.; Loo, J. A.; Maynard, H. D. Nat. Chem. 2013, 5, 221.

(23) Wesolowski, J.; Alzogaray, V.; Reyelt, J.; Unger, M.; Juarez, K.; Urrutia, M.; Cauerhff, A.; Danquah, W.; Rissiek, B.; Scheuplein, F.; Schwarz, N.; Adriouch, S.; Boyer, O.; Seman, M.; Licea, A.; Serreze, D.; Goldbaum, F.; Haag, F.; Koch-Nolte, F. Med. Microbiol. Immunol. 2009, 198, 157.

(24) Huang, L.; Muyldermans, S.; Saerens, D. Expert Rev. Mol. Diagn. 2010, 10, 777.

(25) de Marco, A. Microb. Cell Fact. 2011, 10, 44.

(26) Wong, L. S.; Khan, F.; Micklefield, J. Chem. Rev. 2009, 109, 4025.

(27) Jonkheijm, P.; Weinrich, D.; Schroeder, H.; Niemeyer, C. M.; Waldmann, H. Angew. Chem., Int. Ed. 2008, 47, 9618.

(28) Aida, T.; Meijer, E. W.; Stupp, S. I. Science 2012, 335, 813.

(29) Mager, M. D.; LaPointe, V.; Stevens, M. M. Nat. Chem. 2011, 3, 582.

(30) Rybtschinski, B. ACS Nano 2011, 5, 6791.

(31) Jun, H. W.; Yuwono, V.; Paramonov, S. E.; Hartgerink, J. D. Adv. Mater. 2005, 17, 2612.

(32) Nallur, S. K. M.; Voskuhl, J.; Bultema, J. B.; Boekema, E. J.; Ravoo, B. J. Angew. Chem., Int. Ed. 2011, 50, 9747.

(33) Lee, D.-W.; Park, K. M.; Banerjee, M.; Ha, S. H.; Lee, T.; Suh, K.; Paul, S.; Jung, H.; Kim, J.; Selvapalam, N.; Ryu, S. H.; Kim, K. Nat. Chem. 2011, 3, 154.

(34) Kim, C.; Agasti, S. S.; Zhu, Z.; Isaacs, L.; Rotello, V. M. Nat. Chem. 2010, 2, 962.

(35) Meyer, R.; Niemeyer, C. M. Small 2011, 7, 3211.

(36) Dankers, P. Y. W.; Harmsen, M. C.; Brouwer, L. A.; Luyn, M. J. A.; Meijer, E. W. Nat. Mater. 2005, 4, 568.

(37) Krogman, K. C.; Lowery, J. L.; Zacharia, N. S.; Rutledge, G. C.; Hammond, P. T. Nat. Mater. 2009, 8, 512.

(38) Shah, R. N.; Shah, N. A.; Del Rosario Lim, M. M.; Hsieh, C.; Nuber, G.; Stupp, S. I. Proc. Natl. Acad. Sci. U.S.A. 2010, 107, 3293.

(39) Liu, Y.; Wang, H.; Kamei, K. I.; Yan, M.; Chen, K.-J.; Yuan, Q.; Shi, L.; Lu, Y.; Tseng, H.-R. Angew. Chem., Int. Ed. 2011, 50, 3058.

(40) Yang, L.; Gómez-Casado, A.; Young, J. F.; Nguyen, N. D.; Cabanas-Danés, J.; Huskens, J.; Brunsveld, L.; Jonkheijm, P. J. Am. Chem. Soc. 2012, 134, 19199.

(41) González-Campo, A.; Brasch, M.; Uhlenheuer, D.; GómezCasado, A.; Yang, L.; Brunsveld, L.; Huskens, J.; Jonkheijm, P. Langmuir 2012, 28, 16364.

(42) Tian, F.; Cziferszky, M.; Jiao, D.; Wahlström, K.; Geng, J.; Scherman, O. A. Langmuir 2011, 27, 1387.

(43) An, Q.; Brinkmann, J.; Huskens, J.; Krabbenborg, S.; de Boer, J.; Jonkheijm, P. Angew. Chem., Int. Ed. 2012, 51, 12233.

(44) Neirynck, P.; Brinkmann, J.; An, Q.; van der Schaft, D.; Gustav Milroy, L.; Jonkheijm, P.; Brunsveld, L. Chem. Commun. 2013, 49, 3679.

(45) Boekhoven, J.; Rubert Pérez, C. M.; Sur, S.; Worthy, A.; Stupp, S. I. Angew. Chem., Int. Ed. 2014, 52, 12077.

(46) Park, K. M.; Yang, J.-A.; Jung, H.; Yeom, J.; Park, J. S.; Park, K.H.; Hoffman, A. S.; Hahn, S. K.; Kim, K. ACS Nano 2012, 6, 2960. 
(47) Brinkmann, J.; Cavatorta, E.; Sankaran, S.; Schmidt, B.; van Weerd, J.; Jonkheijm, P. Chem. Soc. Rev. 2014, 43, 4449-69.

(48) Vukicevic, S.; Grgurevic, L. Cytokine Growth Factor Rev. 2009, 20, 441.

(49) Li, R. H.; Wozney, J. M. Trends Biotechnol. 2001, 19, 255.

(50) Kemmis, C. M.; Vahdati, A.; Weiss, H. E.; Wagner, D. R. Biochem. Biophys. Res. Commun. 2010, 401, 20.

(51) van der Linden, R. H. J.; Frenken, L. G. J.; de Geus, B.; Harmsen, M. M.; Ruuls, R. C.; Stok, W.; de Ron, L.; Wilson, S.; Davis, P.; Verrips, C. T. Biochim. Biophys. Acta, Protein Struct. Mol. Enzymol. 1999, 1431, 37.

(52) Spinelli, S.; Frenken, L. G. J.; Hermans, P.; Verrips, T.; Brown, K.; Tegoni, M.; Cambillau, C. Biochemistry 2000, 39, 1217.

(53) De Genst, E.; Silence, K.; Decanniere, K.; Conrath, K.; Loris, R.; Kinne, J. r.; Muyldermans, S.; Wyns, L. Proc. Natl. Acad. Sci. U.S.A. 2006, 103, 4586.

(54) González-Campo, A.; Eker, B.; Gardeniers, H. J. G. E.; Huskens, J.; Jonkheijm, P. Small 2012, 8, 3531.

(55) Ludden, M. J. W.; Mulder, A.; Schulze, K.; Subramaniam, V.; Tampé, R.; Huskens, J. Chem.-Eur. J. 2008, 14, 2044.

(56) Ludden, M. J. W.; Mulder, A.; Tampé, R.; Reinhoudt, D. N.; Huskens, J. Angew. Chem., Int. Ed. 2007, 46, 4104.

(57) Lata, S.; Reichel, A.; Brock, R.; Tampé, R.; Piehler, J. J. Am. Chem. Soc. 2005, 127, 10205.

(58) De, M.; Rana, S.; Rotello, V. M. Macromol. Biosci. 2009, 9, 174.

(59) Voskuhl, J.; Brinkmann, J.; Jonkheijm, P. Curr. Opin. Chem. Biol.

2014, 18, 1-7.

(60) Gomezcasado, A.; Dam, H. H.; Yilmaz, D.; Florea, D.; Jonkheijm, P.; Huskens, J. J. Am. Chem. Soc. 2011, 133, 10849.

(61) Nakamura, I.; Makino, A.; Ohmae, M.; Kimura, S. Macromol. Biosci. 2010, 10, 1265.

(62) van der Horst, G.; van Bezooijen, R. L.; Deckers, M. M. L.; Hoogendam, J.; Visser, A.; Löwik, C. W. G. M.; Karperien, M. Bone 2002, 31, 661-9.

(63) van der Horst, G.; van der Werf, S. M.; Farih-Sips, H.; van Bezooijen, R. L.; Löwik, C. W.G. M.; Karperien, M. J. Bone Miner. Res. 2005, 20, 1867.

(64) Tsai, M.-T.; Li, W.-J.; Tuan, R. S.; Chang, W. H. J. Orthop. Res. 2009, 27, 1169.

(65) Wasserberg, D.; Nicosia, C.; Tromp, E. E.; Subramaniam, V.; Huskens, J.; Jonkheijm, P. J. Am. Chem. Soc. 2013, 135, 3104. 